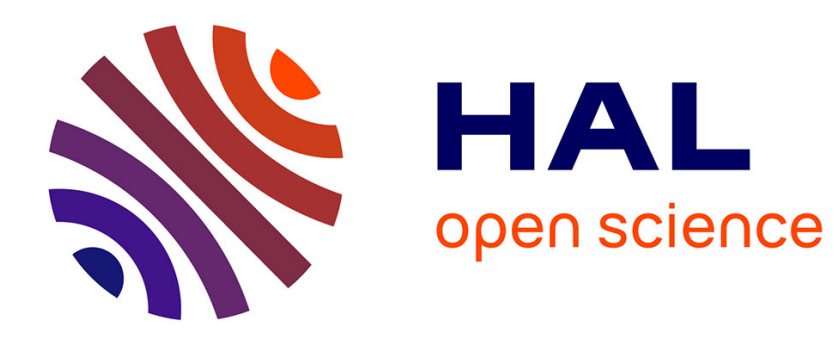

\title{
Telecommunications, the Internet and Mr Schumpeter
} Jackie Krafft

\section{To cite this version:}

Jackie Krafft. Telecommunications, the Internet and Mr Schumpeter. H. Hanusch and A. Pyka. Elgar Companion to Neo-Schumpeterian Economics, Edward Elgar, pp.621-632, 2007. hal-00211744

\section{HAL Id: hal-00211744 \\ https://hal.science/hal-00211744}

Submitted on 21 Jan 2008

HAL is a multi-disciplinary open access archive for the deposit and dissemination of scientific research documents, whether they are published or not. The documents may come from teaching and research institutions in France or abroad, or from public or private research centers.
L'archive ouverte pluridisciplinaire HAL, est destinée au dépôt et à la diffusion de documents scientifiques de niveau recherche, publiés ou non, émanant des établissements d'enseignement et de recherche français ou étrangers, des laboratoires publics ou privés. 


\title{
Telecommunications, the Internet
}

\author{
and Mr Schumpeter
}

\author{
Jackie Krafft
}

CNRS-IDEFI-LATAPSES

Contribution for the Elgar Companion Series on Neo-Schumpeterian Economics, Horst Hanusch and Andreas Pyka (eds.), Cheltenham: Edward Elgar. 


\section{Introduction}

Joseph Schumpeter is certainly one of the $20^{\text {th }}$ century economists who insisted most on the evolution and viability of capitalism. In his seminal contribution to economics, and especially in his 1912 and 1942 volumes, he largely discussed the emergence and decline of leading industries in the development of capitalist economic systems. To him, the internal dynamics of industries had a strong impact on economic growth of modern economies and, as such, was a key field of investigation (Hanusch, 1999; Metcalfe, 1997; Malerba and Orsenigo, 1996; Hertje, 1987). These assertions are clearly at the core of a timely debate. In the early $21^{\text {st }}$ century, modern economies are much affected by the evolution of a specific industry, the telecommunications industry, which today includes activities such as the Internet and electronic commerce, and is also highly connected to computing, software, semiconductors and the media. This industry promised so much in terms of innovation, employment, creation of new business companies, economic development and growth, that it was generally considered at the origins of a so-called 'new economy'. In less than a couple of years, however, this industry finally turned out to be the leading factor of one of the largest industrial collapse ever observed, running more traditional industries into high turbulence and shakeout.

The purpose of this chapter is thus to understand the ups and downs of this industry, and especially to identify in Schumpeter's vision of capitalism what could be the determinants of such an evolution. In a nutshell, the paper will investigate to what extent the key notions of Schumpeter's analysis - which include economic development 
and creative destruction, entrepreneurship and large firms, patterns of industry dynamics and evolution, competition as a process, and invention and innovation - can shed a new light on the evidence of the rise and decay of the telecommunications industry viewed as an exemplifying and central figure of modern economic capitalism.

\section{Economic development: the complex evolution process}

\section{driving the industry}

Schumpeter argues that in dealing with capitalism we are dealing with an evolutionary process. It is by nature a form of method of economic change and not only never is, but never can be stationary. In telecommunications, this argument is particularly central since there is a complex evolution process which drives the industry, and which can only be partially described within a static vision (Fransman, 2002; Antonelli, 2003).

There is first a quantitative evolution process which proceeds from the emergence of a number of new communications technologies (optical fibre, DSL, radio access, Ethernet, frame relay, ISDN, ATM), and which is also associated to an increasing demand for services (fixed and mobile telephony, Internet and online services). This quantitative evolution resulted into important industrial reconfigurations. In most industrialized countries, the historical incumbent monopoly (incumbent telecommunications operator, "incumbent telco" thereafter) which controlled the technological infrastructure and related services was soon contested by a limited number of new entrants during part liberalization in the 1980s. In the US, for instance, $A T \& T$ faced MCI and Sprint as new entrants; in the UK, British Telecom competed with 
Mercury-Cable\&Wireless; and in Japan, NTT was contested by DDI, Japan Telecom, and Teleway Japan. During full liberalization in the 1990s, a larger number of new telcos entered the industry. Ex-monopolies in continental Europe such as France Telecom, Deutsche Telecom, or Telecom Italia were challenged by around 100 to 150 new competitors, among which Worldcom, GTS, Colt, Vodafone were the most aggressive. On average over the period 1998-2002, entry rates ranged between 15 to $20 \%$ per year and a fierce competition in terms of new services and markets, infrastructures and technologies, took place between incumbents, new entrants (from part-liberalization) and latecomers (from full liberalization).

Second, the evolution process is also qualitative since the traditional telecommunications industry, in which incumbent telcos were the key actors, was progressively transformed into a new industry, the info-communications industry, which today includes and merges companies formerly separated and undertaking activities such as computing, software, semiconductors, the Internet and electronic commerce, and the media. Beside telcos, other companies such as component and equipment suppliers (Lucent, Nortel, Alcatel, Siemens, Cisco, Nokia), Internet access providers and Internet service providers (IAPs and ISPs: Wanadoo, T-online), navigation and middleware companies (Netscape, Yahoo), and Internet content providers (ICPs: Bloomberg, Reuters, AOL Time Warner, Vivendi Universal) have emerged as major actors and contributed to shape the new industry dynamics. On the supply side, thus, the industry is becoming more and more complex while in the meantime the demand side still expands, but at growth rates far lower than what was expected. The combination of supply and demand characteristics led the telecommunications industry to experience in 
the early 2000s dramatic coordination failures, including over-investment, excess capacity, downsizing, and a sharp fall in the share prices, revenue and profitability, which also diffused to user and connected industries.

What we observe is thus an industry which has faced radical transformations in a recent past, and which today attempts to survive to major coordination failures (Mc Knight and Bailey, 1997; Bohlin and Levin, 1998; Abbate, 1999; Madden, 2003). The story to be told is complicated by the fact that this industry is composed of a large variety of companies. Some are incumbents and others new entrants; some are investing a lot in R\&D and others not; some are facilities-based and others are facilities-less; some are vertically integrated while others are highly specialized; some are large others small. The key issue to be explored within a Schumpeterian perspective is certainly to what extent these different companies will be able to survive, and further will recover their position of economic booster.

\section{Efficient allocation versus creative destruction: regulation}

\section{and industry dynamics}

Schumpeter's critical discussion about the static optimal allocation of resources in case of perfect competition, as opposed to the dynamic efficiency of monopolistic structures with regard to innovative activities, also contributes to reconsider what occurred in the telecommunications industry over the last twenty years. The key problem is that while the telecommunications dynamics is essentially driven by a creative destruction of resources in which large and small companies play a key role, regulation has essentially 
been oriented towards the approximation of a perfect competition situation. This gap between industry dynamics on the one hand, and regulation on the other, can be illustrated by two examples which contributed to disturb the telecommunications industry.

The first example concerns the first wave of liberalization in the 1980s. Within the regulators vision of the telecommunications industry, the nature of end-users requirements was to some extent pre-established (exogenous), and liberalization was intended to favor the emergence of a less concentrated industrial structure to sustain technological efficiency. Over this period, telcos were thus induced to adjust their price below a certain average level (so-called price cap) determined by the regulator, the individual prices being intended to reflect costs and demand elasticities. This pricing regime was implemented to encourage companies to (i) improve their efficiency by developing profit-making incentives to decrease costs, (ii) invest efficiently in new plants and facilities, and (iii) develop and deploy innovative service offerings. Today, with the experience of liberalization, we know that if points (i) and (ii) were achieved, price caps did not provide firms with sufficient incentives to achieve point (iii). The rate structure generally imposes a costly, time-consuming, and unnecessary burden on companies and significantly impeded the introduction of new advanced services. This point was recurrently emphasized in regulation reports in US and Europe since the mid 1990 s.

The second example is related to the $3 \mathrm{G}$ auction process which occurred within the second wave of liberalization in the 1990s in most industrialized countries. For the 
regulators, this process of allocation of a scarce resource (the hertzien spectrum) was efficient for two major reasons (see Klemperer, 2000). First, it was supposed to improve the welfare of final customers which could access a superior technology ( $3 \mathrm{G}$ mobile phones based on UMTS technologies) with no major increases in prices in associated services. In the ideal world of competition, a rational firm is only supposed to take into account its own forward looking costs and revenues and the likely behavior of rival firms. In this perspective, the license fee which is a sunk cost for all firms is deemed not to affect price. Second, the auction system was supposed to accelerate the rolling out of $3 \mathrm{G}$ mobile phones by providing telcos with adequate incentives to innovate. The costs supported by these companies could only be covered if $3 \mathrm{G}$ services quickly started contributing a significant amount of revenues. Here again, with the experience of the auction system, we know that the prominence of efficient allocation objectives supported by regulation had huge negative effects on the telecommunications industry dynamics. Most of the companies involved in the auction system, either directly (such as the telcos) or indirectly (such as the equipment providers and advanced service and content providers), faced major problems of indebtedness due to the effective burden of the sunk costs. Moreover, the experience of the $3 \mathrm{G}$ auction system had also pervasive effects concerning the technologies effectively created and diffused. Apparently, the targeted techno-innovation system - UMTS-driven - tends to be superseded by less advanced and competing technologies, such as the Japanese I-mode system which corresponds to a 2.5 generation of mobile phones.

Schumpeter told us that innovations led to cyclical fluctuations whose length was determined by both the character and the period of implementation of the innovations. 
Moreover, the combination of the use of the innovations, overinvestment and of credit expansion going too far, was supposed to bring the upswing to an end. With this in mind, we can thus interpret the two former regulation orientations quite as much as recurrent shocks which either prevented innovation to be developed, or greatly disturbed the innovation process.

\section{Large companies and innovation}

Schumpeter recurrently stressed his preference for monopoly and oligopoly, and thus conversely his disdain for free competition, when innovative activities are involved Telecommunications has traditionally been an industry where large companies operate and constitute the core business. Before liberalization, natural monopolies prevailed at the national level, and though some of them were broken up with liberalization $(A T \& T$ in the 1980s, and $B T$ in the 1990s), the development of economies of scale and network effects tends to favour large firms and oligopoly structures. This is also increasingly true in other complementary activities such as the equipment provision, the Internet end-to-end connectivity, navigation, middleware and content. But is this industry still innovative? We know that in the old days, telecommunications were associated with large and famous research centres, such as Bell Labs in the US, CNET in France, Martlesham Laboratories in the UK. What happened to these centres in the liberalization era? Does the current industrial structure provide the adequate creation and diffusion of new knowledge? 
If we investigate, first, technological innovation which includes the Schumpeterian notion of 'new combination' leading to the development of a new product, or a new method of production, we have to consider the "upstream" part of the industry, namely the equipment suppliers and telcos. With liberalization, incumbent telcos which formerly were the main technology providers had to face a fierce price competition from new entrants. In many cases, incumbents decided to delegate their R\&D activity to the equipment suppliers which thus became key actors in the industry. In a few years, the initial split of R\&D expenses (on average, $15 \%$ in revenue for telcos and $5 \%$ for equipment suppliers) was completely reversed (thus $5 \%$ in revenue for telcos and $15 \%$ for equipment suppliers). Research centres which were for a long time incorporated within the telecommunications public administration were transformed into subsidiaries of incumbent telcos (Martlesham Laboratories became BT Exact Technologies, CNET became France Telecom $R \& D$ ) or incorporated within equipment suppliers structure (Bell Labs is part of Lucent). With these transformations, technological innovations were essentially delivered by equipment suppliers which became increasingly specialized in $\mathrm{R} \& \mathrm{D}$, and largely favoured the development of new modes of communications such as IP access and mobile telecommunications on the basis of radio access, satellite connections and optical fibres. This vertical specialization greatly stimulated the penetration of new telcos by decreasing technological barriers to entry (see Fransman, 2002).

If we now turn to organizational innovation, which is more closely related to the opening up of new markets and the reorganization of sectors of the economy (both considered as 'new combinations' by Schumpeter), the "downstream" part of the 
industry including Internet connectivity, navigation, middleware and content provides a wide range of case studies. For instance, the end-to-end connectivity field of activity which provides customers with access to the Internet and basic applications such as email and web hosting were initially developed in the early 1990s by large telcos (MCI and Sprint in the US, France Telecom Oléane in France) and major science foundations (the NSF in the US, Renater in Europe). Advanced fields of applications such as Internet browsers, search engines, directory assistance, security in data transfer, electronic payments, on-line services and broadcasting services have also been shaped by large companies such as AOL Time Warner, Microsoft, IBM, Vivendi Universal, Bloomberg and Reuters. Though some of these companies are now involved in a somewhat chaotic evolution, the pace of change in the creation of new markets, the convergence and mutation of existing markets, and to some extent the development of an Internet and mobile economy seemed to be essentially driven by large, vertically related companies (Krafft, 2003).

\section{Entrepreneurship and market process}

The entrepreneur plays a central role in Schumpeter's work. He is the innovator, and the agent of economic change and development. He has disequilibriating role in the market process by applying new combinations of factors of production, and by interrupting the circular flow of economic life which is the ongoing production of existing goods and services under existing technologies and methods of production and organization. In the 1990 s, with the emerging separation in industrial organisation of i) the R\&D function undertaken by equipment suppliers, ii) the network function (wireline, wireless, mobile 
and IP) operated by facilities-based telcos, and iii) the service function (connectivity, navigation, middleware, content for mobile and fixed telecommunications) provided by facilities-less companies, the rise of new entrepreneurship became a central feature of the market process in telecommunications. While a technological background was necessary to venture a new start-up in telecommunications $R \& D$, the field of activity of equipment suppliers, this condition was not necessary for the other functions, namely the network and service function. New companies entered the industry without any technological competences, since technology was provided by equipment suppliers. Moreover, they could penetrate the market without a proprietary network, by leasing the lines and infrastructure of incumbents or other former entrants (Kavassalis and Salomon, 1997). In fact, they could gain a competitive advantage by developing new marketing services, and new but low price applications, all strategies which were beyond the scope of the traditional experience of incumbent monopolies.

In the upturn period of the telecommunications industry, reference was thus recurrently made to the 'gifted few', the 'gurus of the new economy', such as George Soros from GTS, or Bernard Ebbers from Worldcom, pioneering in the field of new technologies, new products and new markets. These entrepreneurs initially operated in an unstable world, and were generally swimming against the tide of society which saw the telecommunications industry as a complex techno-economic system providing a limited set of applications. Quite rapidly, these new companies outperformed their incumbent competitors and registered incredibly high stock market capitalization. The total stock market value of all telecommunications companies reached the maximum level of 6,500 billion $\$$ in March 2000. But at the end of 2001, nevertheless, the bubble exploded and 
the value fall down to 4,000 billion $\$$. The downturn period then started, with a net diminution of new entries, the exit of existing companies including the largest ones (Worldcom, GTS...), and thus high turbulence and shakeout.

Today, a new process of entry re-emerges but on somewhat different conditions. First, a technological background seems to be a pre-requisite for any new start-ups, even for those which are facilities-less and operating in the service field of activities. Second, the connection to i) large, established companies and ii) universities and academic research institutes appears also as a pre-condition for performing as a business company, and especially for being financed as a start-up. The post-shakeout era of telecommunications will thus apparently be increasingly characterized by the emergence and development of innovation networks (in which companies, universities, norms and standards organisms, and even venture capitalists and financial institutions will be involved), a characteristic which was absent of the pre-shakeout period of development.

\section{Destroying the old and creating the new: lessons for}

\section{industry dynamics}

The recession, which in Schumpeter's view is a healthy phase of restructuring, paving the way for a new burst of future innovations. The decay of capitalism is based on the vision that it is not economic failure, but rather economic success that causes major coordination failures. Is this vision helpful for understanding the recent evolution of the telecommunications industry? 
On the one hand, what the Schumpeterian vision tell us is certainly that the appearance of entrepreneurs in bursts is due exclusively to the fact that the appearance of one or a few entrepreneurs facilitates the appearance of others, and that the downturn sets in as a result of smaller profit margins due to imitation. To some extent, and according to this vision, the massive entry process which occurred in the telecommunications industry in the 1990s contained in itself the promise of a period of decline. As already mentioned, the viability of a large number of companies was possible if the extent of market was also growing in size, or at least was evolving by a multiplication of profitable niches. But this did not happen, and the rate of growth of the market at the time of its emergence is not comparable to the rate of growth of the same market at the age of maturity. Moreover the shocks imposed to the industry, such as the $3 \mathrm{G}$ auction system, certainly contributed to erode the margins of companies which were faced, on the technological side, to a radical process of change and, on the demand side, to a still evolving pattern of demand both in terms of characteristics and habits. This vision, which is a core aspect in Schumpeter's analysis, was totally neglected or superseded by mainstream conceptions which essentially focus on an ideal world of perfect predictions. The recent telecommunications history gives another evidence that this latter conception and associated equilibrium framework cannot hold when radical innovation is present.

But, on the other hand, what Schumpeter doesn't tell us is that creating the new does not involve necessarily destroying the old. To some extent, the new companies which entered the industry and which were supposed to outperform the incumbents did not 
drove these incumbent companies to exit the industry. Though some decisive attempts were made by new entrants to dominate the incumbents (in the US, for instance, Worldcom, the new entrant of a full-liberalization cohort acquired $M C I$, an entrant of a part-liberalization cohort), these are the new entrants which in the 2000s finally exited the industry and faced shakeout and turbulence more sharply. Schumpeter thus envisaged a broad dynamic qualitative analysis of the emergence, development and decline of industries, but since he did not enter into the details of how industries change over time in terms of their structural features and forms of organization, failed to provide a global analysis of industry dynamics. One of the complementary reasons is also certainly that in the days he wrote, industries started from scratch with a new entrepreneur setting up a firm to introduce his invention. Then this firm was supposed to grow and to hold a monopoly position for some time, until this firm was finally imitated by new entrants which competed severely and drove the initial firm to exit the industry. Today, and especially from what occurred in the telecommunications industry, industry dynamics seems to be quite different. Industries generally arise from the transformation of existing industries. For instance, the Internet and mobile companies did not emerged ex-nihilo, but were from the start highly related to the traditional wireline telecommunications industry. When a shakeout occurs, firms which organized the conditions of knowledge accumulation and diffusion, such as the incumbent telecommunications companies, may survive to the introduction of novelty and eventually become the leaders of the newly-born industry. As a matter of fact, incumbent telcos are today key actors of the emerging info-communications industry. 


\section{The process of competition}

Competition was analysed by Schumpeter as a process of creative destruction the implications of which were already mentioned in paragraph 3 . Within this notion of competition, cost and quality advantages are much decisive than price competition, and involve a longer term survival for companies which contribute to the economic development. But, here again, the analysis of the telecommunications industry drives to a paradox, or at least to a situation which was not envisaged by Schumpeter.

The first cohort of entrants, namely entrants coming from the first wave of partliberalization in the 1980 s, essentially engaged a fierce rivalry in terms of price with the incumbent. The outcome of this first competitive process was thus important decreases in prices (from $-30 \%$ to $-50 \%$ for long distance and international calls; and $-10 \%$ to $20 \%$ for local communications), accompanied by a fundamental tariff rebalancing between subscription charges and communications tariffs. Within the former monopoly situation, subscription charges were insufficient to cover the costs of local wireline network, while domestic long distance and international tariffs were high relative to underlying costs. The second cohort of entrants, issued from full-liberalization in the 1990s, privileged a strategy of low cost and high quality provision of telecommunications network and services. These entrants largely contributed to (i) the elaboration of an open set of communications applications such as voice, texts, graphs, sounds, fixed images or videos; (ii) the emergence of communications between groups of users based on new patterns of infrastructures and services, mobile and Internet oriented; (iii) the development of end-users friendliness, reliability and safety relying on 
high performance networks; and (iv) the consideration of mobility of equipment premises, end-user, services, and even of different elements within the network. According to Schumpeter, we can consider these new entrants as key actors in the process of competition which occurred in telecommunications, as dynamic and innovative players compared to the first cohort of entrants which essentially behaved as imitators of the incumbents.

Within a Schumpeterian vision, the fittest new entrants of the second cohort would have then survive better than the former new entrants. The selection process which occurred in the telecommunications industry, nevertheless, drove to the recomposition of a stable oligopoly, essentially composed of incumbents and entrants of the first cohort. This outcome which is counter-intuitive may be explained by a central element. The competition which was implemented in the telecommunications industry should have been coordinated more adequately by competitive and regulation authorities, since innovative activities were an essential part of the process. The coordination which was effectively implemented by competitive and regulation authorities essentially concerned tariff rebalancing and interconnection fees issues, while in the meantime innovative activities characterized by the development of a qualitative change in telecommunications were entirely left to the market. This central element involved the entry of a large number of new companies which invested massively in networks and services, and resulted thus in excess capacity with incumbents still in place. The overlapping of two major technological trajectories, the one supported by incumbents and entrants of the first cohort and the other by entrants of the second cohort, would 
have required a deeper coordination in terms of shared infrastructure, planned investment processes, which failed to materialized in the concrete world.

\section{Invention and innovation}

For Schumpeter, innovation is a central feature of economic development, and this was already mentioned in paragraph 3. But, moreover, innovations must be distinguished from inventions. The application of new combinations by entrepreneurs is possible without inventions, while inventions as such need not necessarily lead to innovations and need not to have any economic consequences. This distinction is useful to understand the changes which occurred in the industry at the age of the Internet and mobile communications (Antonelli, 2003). In fact, the research centres associated to the incumbent telcos were in the early 1980 s the essential inventors of packet-switching technologies and cellular mobile systems. But clearly these inventions which were the fruit of a high level of excellence of academic institutes specialized in telecommunications research did not materialize into economic development. At that time, inventions were kept within the scientific sphere, and incumbent monopolies did not consider the opportunity to transform these inventions into innovations and commercial opportunities. Part-liberalization did not introduce many changes to this fact that the telecommunications industry was more inventive than innovative.

Innovation is thus a relatively recent key feature of the telecommunications industry. First because equipment suppliers now in charge of the research and development of the industry attempted more systematically and more rapidly to coordinate invention with 
innovation, and to provide the large number of new entrants in the full-liberalization era with adapted and commercialised technologies. Second, because these new entrants with a small technological background were also induced by competition to elaborate new combinations for a larger and diversified set of applications.

In the post shakeout era, nevertheless, one may question the viability of patterns of invention or innovation since i) research departments and subsidiaries have been involved into a large process of restructuring which concerns equipment suppliers and telcos, and which generally implies important budget cuts in these companies, and eventually downsizing due to the important perturbations in terms of profitability, revenues and share price; ii) major leaders in innovative combinations for the creation of new market and services have been much affected by the telecommunications crisis, and many of these new entrants went to bankruptcies. Can we thus consider that in a near future the telecommunications industry will be a field of activity where invention and innovation are absent? The current tendency is that, despite major perturbation in this industry, invention and innovation still continue to be developed, and especially technological innovation. The development of I-mode and Wireless Lans which are competing technological systems of the UMTS start to be largely diffused worldwide. But an important change is nevertheless occurring: Wireless Lans were developed by companies coming from the computer industry. Thus, the telecommunications industry can be considered as innovative and inventive, provided it is merged into a larger industry including now telecommunications and computer activities. 


\section{Conclusion}

One of the main outcome of this chapter is to show that Schumpeter is still vividly central in the understanding of the evolution of industries, and especially the telecommunications industry in which major changes occurred in terms of competition, innovation, technologies, services, incumbents and entrants. His methodology centred on the explanation of economic development and creative destruction issues, rather than efficient allocation and pricing issues, proves to be particularly adapted to the telecommunications industrial dynamics. In the meantime, however, the complexity of this industry, and the natural evolution of modern capitalism in itself, render difficult a pure application of his global and initial framework. Especially, the current reemergence of stable oligopoly composed of incumbent companies is to some extent a key puzzle for Schumpeterian economics which is still left unresolved.

\section{References}

Abbate, J., 1999, Inventing the Internet, Cambridge: MIT Press.

Antonelli, C., 2003, The Economics of Innovation, New Technologies and Structural Change, London: Routledge.

Bohlin, E., and Levin, S. (eds.), 1998, Telecommunications Transformation: Technology, Strategy and Policy, IOS Press.

Fransman, M., 2002, Telecoms in the Internet Age: From Boom to Burst to..., Oxford: Oxford University Press. 
Hanusch, H. (ed), 1999, The Legacy of Joseph Alois Schumpeter, Cheltenham: Edward Elgar.

Heertje, A., 1987, "Schumpeter, Joseph Alois", The New Palgrave,

Kavassallis, P., and Salomon, J., 1997, "Mr Schumpeter on the Telephone: Patterns of Technical Change in the Telecommunications Industry Before and After the Internet, Communications \& Strategies, 26: 371-408.

Klemperer P. (ed.) (2000) The Economic Theory of Auctions, Cheltenham : Edward Elgar.

Krafft, J., 2003, "Vertical Structure of the Industry and Competition: an Analysis of the Evolution of the Info-communications Industry, Telecommunications Policy, forthcoming.

Madden, G. (Ed), 2003, Handbook on Telecommunications, Cheltenham: Edward Elgar. (forthcoming)

Malerba, F., and Orsenigo, L., 1996, "The Dynamics and Evolution of Industries, Industrial and Corporate Change, 5(1), 51-87.

Metcalfe, S., 1997, Evolutionary Economics and Creative Destruction, London: Routledge.

McKnight, L., and Bailey, J., (eds), 1997, Internet Economics, Cambridge, Mass., MIT Press.

Schumpeter, J.A., 1912, The Theory of Economic Development, Leipzig: Duncker \& Humblot. Trans. R. Orpie, Cambridge, Mass.: Harvard University Press, 1934. Reprinted, New York: Oxford University Press, 1961.

Schumpeter, J.A., 1942, Capitalism, Socialism and Democracy, New York: Harper \& Brothers, London: George Allen \& Unwin, 1976. 